\title{
Anti-Schistosomal Activity of Medicinal Plants: Mini Review
}

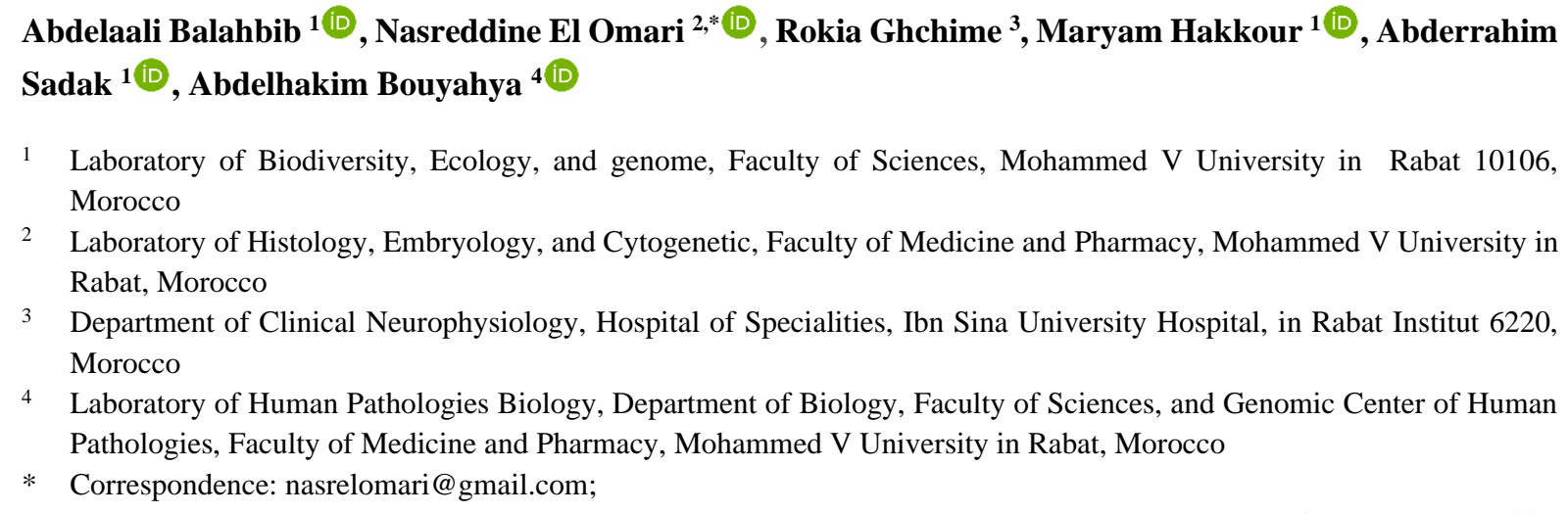

Received: 2.10.2020; Revised: 2.01.2021; Accepted: 5.01.2021; Published: 17.01.2021

\begin{abstract}
Schistosomiasis is a parasitic disease caused by the Schistosoma genus' parasites, and several complications associated with this pathology can lead to death. Indeed, Schistosoma mansoni and Schistosoma haematobium are the major species responsible for this disease, spreading particularly in Africa. While synthetic drugs used to treat Schistosomiasis are often not effective and represent major side effects. In this context, many research teams are currently focusing on identifying natural secondary metabolites with anti-schistosomal properties. Therefore, this work highlighted an overview of some medicinal plants' anti-schistosomal activity and their bioactive compounds.
\end{abstract}

Keywords: Schistosomiasis; medicinal plants; bioactive compounds; anti-schistosomal activity.

(C) 2020 by the authors. This article is an open-access article distributed under the terms and conditions of the Creative Commons Attribution (CC BY) license (https://creativecommons.org/licenses/by/4.0/).

\section{Introduction}

Schistosomiasis is a tropical disease caused by worms of the genus Schistosoma, affecting between 230 and 250 million worldwide [1]. It is transmitted by freshwater mollusks, which act as intermediate hosts [2]. This infection remains a major public health problem in developing countries. The two major species that caused human Schistosomiasis are S. mansoni and S. haematobium, responsible for intestinal and urinary Schistosomiasis, respectively, spread out mainly in Africa [3].

Praziquantel (PZQ) and oxamniquine are the classic treatments for human schistosomiasis [4]. However, these drugs have limitations; they cause frequent treatment failures, high rates of reinfection [5], and, in some cases, specific resistance against praziquantel [6]. In addition to treating the infected individuals, snail control with molluscicides (Niclosamide, sodium pentachlorophenate, and tributyltin oxide) has been mandatory to reduce the risk of schistosomiasis transmission in endemic areas [7]. However, it presents major risks for the environment and human health.

It is necessary to find effective treatments, less expensive, and with little undesirable effects in this context. Moreover, phytotherapy is a promising alternative in managing parasitic 
diseases $[8,9]$, notably bilharziasis. Indeed, several studies have evaluated anti-schistosomal power using medicinal plants and their bioactive compound [10,11].

\section{Overviews on Schistosomiasis}

Bilharziasis is a parasitic disease caused by trematode worms of the genus Schistosoma. It exists in 75 to 76 countries, mainly in Africa, Asia, and South America [12], and can also occur in non-endemic areas. Generally, five Schistosoma species can infect man, including Schistosoma haematobium, Schistosoma mansoni, Schistosoma japonicum, Schistosoma mekongi, and Schistosoma intercalatum [13]. The schistosome has several development stages, including worm, egg, miracidium, schistosomula, sporocyst, and cercaria [14]. The male and female genitals are located face-to-face and allow almost permanent copulation [15]. Adult worms have a lifespan varying from 5 to 32 years, but the average duration of laying varies from 3 to 12 years [16]. Its development cycle is dixene, but it includes an intermediate host (mollusk). The asexual phase of the parasite's reproduction occurs, and a definitive host in which the sexual part of this reproduction occurs $[17,18]$. The disease transmission depends on close contact between humans, the parasite, the intermediate host, and surface water as well as other important factors such as climate, socio-economic level, and population density.

\section{Anti-Schistosomal Activity of Medicinal Plants}

Given that Schistosomiasis remains a global challenge, especially in sub-Saharan Africa, it affects the world's most impoverished populations and subsequently causes significant morbidity and mortality worldwide. Moreover, the existing treatment does not kill immature schistosomes. It has serious adverse effects, and also, the developed resistance limits its effectiveness (infections, therefore, cannot be treated effectively) [19, 20]. It is, therefore, urgently needed to develop alternative drugs for patients. Several studies have reported anthelmintic activities and evaluated the schistosomicidal properties of medicinal plant extracts. These studies showed promising results with efficacy effects against all Schistosoma species and on the parasitic host, giving hope to save the lives of millions of people worldwide. Furthermore, several extracts from the medicinal plant were tested against Schistosoma (Table 1). These species include Plectranthus tenuiflorus, Ocimum americanum, Bridelia micrantha, Peganum harmal, Allium sativum, Clerodendrum umbellatum, Mitracarpus frigidus, Rauwolfia vomitoria, Cleome droserifolia, and Punica granatum [21-46].

\subsection{Anti-schistosomal effects of plant extracts.}

The anti-schistosomal effect medicinal plants depend on several factors, including medicinal plants tested, used methods, and strains tested. Table 1 summarizes the results of different reported studies in the literature on the anti-schistosomal effects of medicinal plant products. Osman and colleagues showed that Peganum harmala seeds exhibit a mortality rate of $100 \%$ during the first half-hour of exposure for all the extracts used at different concentrations [34]. Otherwise, stem and root bark and fruit rind and placenta of Punica granatum tannins revealed an effective in vitro activity on the miracidia of Schistosoma mansoni, which exhibited a cytotoxic effect of $50 \%$ at the concentration of $0.39 \mathrm{ppm}$ [33]. In another study, the methanolic extract of Plectranthus tenuiflorus showed moderate anticercaria and anti-schistosomula activities with $\mathrm{IC}_{50}$ values of 12.29 and $17.39 \mathrm{mg} / 100 \mathrm{~mL}$, respectively. 
Table 1. Anti-schistosomal effects of some medicinal plants.

\begin{tabular}{|c|c|c|c|c|c|c|}
\hline Family & Species & Extract & $\begin{array}{c}\text { In vivo/In } \\
\text { vitro }\end{array}$ & Larvae species & Effect & References \\
\hline Agavaceae & Agave lophantha & $\begin{array}{l}\text { Ethanol } \\
\text { extract }\end{array}$ & In vitro & $\begin{array}{l}\text { Worms of } \\
\text { Schistosoma } \\
\text { mansoni }\end{array}$ & $\mathrm{LC}_{50}=8.2 \mathrm{ppm}$ & [21] \\
\hline \multirow[t]{3}{*}{ Amaranthaceae } & \multirow[t]{3}{*}{$\begin{array}{l}\text { Chenopodium } \\
\text { ambrosioides }\end{array}$} & \multirow{3}{*}{$\begin{array}{l}\text { Hydro- } \\
\text { alcoholic } \\
\text { extract }\end{array}$} & In vitro & Cercariae & $\begin{array}{lll}\begin{array}{l}\text { Increased mortality } \\
\text { cercariae }\end{array} & & \\
\end{array}$ & [40] \\
\hline & & & In vitro & Adult worms & $\begin{array}{l}\text { Increased mortality of } \\
\text { adult worms }\end{array}$ & [40] \\
\hline & & & In vivo & $\begin{array}{lr}\text { Swiss } & \text { mice } \\
\text { infected } & \text { with } \\
\text { cercariae of } S . \\
\text { mansoni }\end{array}$ & $\begin{array}{l}\text { Reduced the eggs in feces } \\
\text { and liver }\end{array}$ & [40] \\
\hline \multirow[t]{2}{*}{ Amaryllidaceae } & \multirow[t]{2}{*}{ Allium sativum } & \multirow[t]{2}{*}{$\begin{array}{l}\text { Methanolic } \\
\text { extracts }\end{array}$} & In vitro & $\begin{array}{l}\text { Schistosoma } \\
\text { mansoni worms }\end{array}$ & $\begin{array}{l}\text { High anti-schistosomal } \\
\text { activity }\end{array}$ & [22] \\
\hline & & & In vivo & $\begin{array}{l}\text { Schistosoma } \\
\text { mansoni worms }\end{array}$ & $\begin{array}{l}\text { A reduction of } 27.6 \% \text { and } \\
21.7 \% \text { in worm burden in } \\
\text { the groups having } \\
\text { received Allium sativum }\end{array}$ & [22] \\
\hline \multirow[t]{9}{*}{ Anacardiaceae } & \multirow[t]{3}{*}{ Lannea schimperi } & $\begin{array}{l}\text { Methanolic } \\
\text { stem bark } \\
\text { extracts }\end{array}$ & In vitro & Cercariae & $\begin{array}{l}100 \% \text { of the mortality was } \\
\text { observed at } 2 \mathrm{mg} / \mathrm{mL}\end{array}$ & [41] \\
\hline & & $\begin{array}{l}\text { Methanolic } \\
\text { stem bark } \\
\text { extracts }\end{array}$ & In vitro & $\begin{array}{l}\text { Adult } \\
\text { Schistosoma } \\
\text { mansoni }\end{array}$ & $\begin{array}{l}\text { Exhibited } 100 \% \text { activity } \\
\text { against adult worms at } \\
\text { the dose range of } 1 \text { to } 2 \\
\mathrm{mg} / \mathrm{ml} \text { after } 48 \text { hours of } \\
\text { exposure }\end{array}$ & [41] \\
\hline & & $\begin{array}{l}\text { Methanolic } \\
\text { stem bark } \\
\text { extracts }\end{array}$ & In vitro & Schistosomula & $\begin{array}{l}\text { Significant activity } \\
\text { against Schistosomula }\end{array}$ & [41] \\
\hline & \multirow[t]{3}{*}{ Searsia longipes } & $\begin{array}{l}\text { Methanolic } \\
\text { stem bark } \\
\text { extracts }\end{array}$ & In vitro & Cercariae & $\begin{array}{l}100 \% \text { mortality was } \\
\text { observed } \begin{array}{c}\text { at } \\
\text { the }\end{array} \\
\text { concentration range of } 1 \\
\text { to } 2 \mathrm{mg} / \mathrm{mL}\end{array}$ & {$[41]$} \\
\hline & & & In vitro & Schistosomula & $\begin{array}{l}\text { Significant activity } \\
\text { against Schistosomula }\end{array}$ & [41] \\
\hline & & & & $\begin{array}{l}\text { Adult } \\
\text { Schistosoma } \\
\text { mansoni }\end{array}$ & $\begin{array}{l}\text { Exhibited } 100 \% \text { activity } \\
\text { against adult worms at } \\
\text { the dose range of } 0.5 \text { to } 2 \\
\mathrm{mg} / \mathrm{mL} \text { after } 48 \text { hours of } \\
\text { exposure }\end{array}$ & [41] \\
\hline & \multirow[t]{2}{*}{$\begin{array}{l}\text { Ozoroa } \\
\text { pulcherrima } \\
\text { Schweinf }\end{array}$} & \multirow[t]{2}{*}{$\begin{array}{l}\text { Methanolic } \\
\text { extracts of } \\
\text { root parts }\end{array}$} & In vitro & $\begin{array}{l}\text { Adult worms of } \\
\text { Schistosoma } \\
\text { mansoni }\end{array}$ & Significant reduction & {$[42]$} \\
\hline & & & In vitro & Cercariae & $\begin{array}{l}\text { Most active on cercariae } \\
\text { with an } \mathrm{LC}_{50} \text { of } 20.65 \\
\mu \mathrm{g} / \mathrm{mL} \text { after } 30 \text { minutes }\end{array}$ & {$[42]$} \\
\hline & $\begin{array}{l}\text { Ozoroa } \\
\text { pulcherrima } \\
\text { Schweinf }\end{array}$ & $\begin{array}{l}\text { Roots } \\
\text { methanolic } \\
\text { extract }\end{array}$ & In vivo & $\begin{array}{l}\text { Liver injury } \\
\text { induced by } \\
\text { Schistosoma } \\
\text { mansoni in mice } \\
\end{array}$ & $\begin{array}{l}\text { Significant reduction of } \\
\text { worm burden and ova } \\
\text { count in the feces, } \\
\text { Liver and intestine }\end{array}$ & [43] \\
\hline \multirow[t]{3}{*}{ Apocynaceae } & \multirow[t]{3}{*}{$\begin{array}{l}\text { Rauwolfia } \\
\text { vomitoria }\end{array}$} & $\begin{array}{l}\text { Ethanol } \\
\text { extract of stem } \\
\text { bark }\end{array}$ & In vitro & $\begin{array}{l}\text { Schistosoma } \\
\text { mansoni, } \\
\text { Cercariae } \\
\end{array}$ & $\begin{array}{l}\mathrm{LC}_{50}=207.4 \mu \mathrm{g} / \mathrm{mL} \text { in } 1 \\
\text { hour }\end{array}$ & [23] \\
\hline & & $\begin{array}{l}\text { Ethanol } \\
\text { extract of the } \\
\text { root }\end{array}$ & In vitro & $\begin{array}{l}\text { Schistosoma } \\
\text { mansoni, } \\
\text { Cercariae } \\
\end{array}$ & $\begin{array}{l}\mathrm{LC}_{50}=1430 \mu \mathrm{g} / \mathrm{mL} \text { in } 1 \\
\text { hour }\end{array}$ & [23] \\
\hline & & $\begin{array}{l}\text { Ethanol } \\
\text { extract }\end{array}$ & In vivo & $\begin{array}{l}\text { Schistosoma } \\
\text { mansoni, } \\
\text { Adult worms }\end{array}$ & $\begin{array}{l}\text { All adult worms exposed } \\
\text { to the concentrations } \\
\text { range of } 250-1000 \mu \mathrm{g} / \mathrm{mL} \\
\text { for both plant parts }\end{array}$ & [23] \\
\hline
\end{tabular}




\begin{tabular}{|c|c|c|c|c|c|c|}
\hline Family & Species & Extract & $\begin{array}{l}\text { In vivo/In } \\
\text { vitro }\end{array}$ & Larvae species & Effect & References \\
\hline \multirow[t]{13}{*}{ Asteraceae } & \multirow[t]{4}{*}{ Ajania nubigena, } & Luteolin & In vitro & $\begin{array}{l}\text { Schistosoma } \\
\text { mansoni }\end{array}$ & $\mathrm{IC}_{50}=5.8 \mu \mathrm{g} / \mathrm{mL}$ & {$[24]$} \\
\hline & & $\begin{array}{l}\text { Linalool oxide } \\
\text { acetate (1) }\end{array}$ & In vitro & $\begin{array}{l}\text { Schistosoma } \\
\text { mansoni }\end{array}$ & $\mathrm{IC}_{50}=36.9 \mu \mathrm{g} / \mathrm{mL}$ & {$[24]$} \\
\hline & & Luteolin & In vitro & $\begin{array}{l}\text { Schistosoma } \\
\text { mansoni, } \\
\text { Schistosomula }\end{array}$ & $\mathrm{IC}_{50}=13.3 \mu \mathrm{g} / \mathrm{mL}$ & {$[24]$} \\
\hline & & Luteolin & In vitro & $\begin{array}{l}\text { Schistosoma } \\
\text { mansoni }\end{array}$ & Activity anti schistosomal & {$[24]$} \\
\hline & $\begin{array}{l}\text { Ageratum } \\
\text { conyzoides }\end{array}$ & Essential oil & In vitro & $\begin{array}{l}\text { Worms of } \\
\text { Schistosoma } \\
\text { mansoni }\end{array}$ & $\begin{array}{l}\text { Interesting } \text { dose- } \\
\text { dependent reduction in the } \\
\text { number of eggs of } S . \\
\text { mansoni }\end{array}$ & {$[25]$} \\
\hline & \multirow[t]{6}{*}{ Baccharis trimera } & $\begin{array}{l}\text { Dichlorometh } \\
\text { ane extract } \\
(\mathrm{DE})\end{array}$ & In vitro & $\begin{array}{ll}\text { Adults } & \text { of } \\
\text { Schistosoma } \\
\text { mansoni }\end{array}$ & $\begin{array}{l}\text { Able to inhibit } 100 \% \text { of } \\
\text { the oviposition in females. }\end{array}$ & {$[26]$} \\
\hline & & $\begin{array}{l}\text { Aqueous } \\
\text { fraction }(\mathrm{AF})\end{array}$ & In vitro & $\begin{array}{l}\text { Adults } \\
\text { Schistosoma } \\
\text { mansoni }\end{array}$ & $\begin{array}{l}\text { Able to inhibit } 100 \% \text { of } \\
\text { the oviposition in females. }\end{array}$ & [26] \\
\hline & & $\begin{array}{l}\text { Aqueous } \\
\text { fraction (AF) }\end{array}$ & In vivo & Juvenile worms & $\begin{array}{l}\text { Female worm total burden } \\
\text { reductions of } 75 \%\end{array}$ & [26] \\
\hline & & $\begin{array}{l}\text { Dichlorometh } \\
\text { ane extract } \\
(\mathrm{DE})\end{array}$ & In vivo & Juvenile worms & $\begin{array}{l}\text { Female worm total burden } \\
\text { reductions of } 68 \%\end{array}$ & {$[26]$} \\
\hline & & $\begin{array}{l}\text { Dichlorometh } \\
\text { ane extract } \\
\text { (DE) }\end{array}$ & In vivo & $\begin{array}{l}\text { Adults of } \\
\text { Schistosoma } \\
\text { mansoni }\end{array}$ & Schistosomicidal effects & {$[26]$} \\
\hline & & $\begin{array}{l}\text { Aqueous } \\
\text { fraction }(\mathrm{AF})\end{array}$ & In vivo & $\begin{array}{l}\text { Adults } \\
\text { Schistosoma } \\
\text { mansoni }\end{array}$ & Schistosomicidal effects & {$[26]$} \\
\hline & Juglans nigra & $\begin{array}{l}\text { Methanolic } \\
\text { extracts }\end{array}$ & In vivo & $\begin{array}{l}\text { Schistosoma } \\
\text { mansoni worms }\end{array}$ & $\begin{array}{l}\text { Moderate anti- } \\
\text { schistosomal activity }\end{array}$ & {$[22]$} \\
\hline & $\begin{array}{l}\text { Tanacetum } \\
\text { vulgare }\end{array}$ & $\begin{array}{l}\text { Methanolic } \\
\text { extracts }\end{array}$ & In vivo & $\begin{array}{l}\text { Schistosoma } \\
\text { mansoni worms }\end{array}$ & $\begin{array}{l}\text { Moderate anti- } \\
\text { schistosomal activity }\end{array}$ & {$[22]$} \\
\hline \multirow[t]{9}{*}{ Caricaceae } & \multirow[t]{9}{*}{ Carica papaya } & $\begin{array}{l}\text { Methanol } \\
\text { extracts }\end{array}$ & In vitro & miracidia & $\mathrm{CL}_{50}=3.4 \mathrm{mg} / \mathrm{L}$ & [44] \\
\hline & & $\begin{array}{l}\text { Ethanol } \\
\text { extracts }\end{array}$ & In vitro & miracidia & $\mathrm{CL}_{50}=15.4 \mathrm{mg} / \mathrm{L}$ & {$[44]$} \\
\hline & & $\begin{array}{l}\text { Butanol } \\
\text { extracts }\end{array}$ & In vitro & miracidia & $\mathrm{CL}_{50}=8.1 \mathrm{mg} / \mathrm{L}$ & [44] \\
\hline & & $\begin{array}{l}\text { Methanol } \\
\text { extracts }\end{array}$ & In vitro & $\begin{array}{l}\text { Cercariae of } S . \\
\text { mansoni }\end{array}$ & $\mathrm{LC}_{90}=13.5 \mathrm{mg} / \mathrm{L}$ & [44] \\
\hline & & $\begin{array}{l}\text { Ethanol } \\
\text { extracts }\end{array}$ & In vitro & $\begin{array}{l}\text { Cercariae of } S . \\
\text { manson }\end{array}$ & $\mathrm{LC}_{90}=80.5 \mathrm{mg} / \mathrm{L}$ & {$[44]$} \\
\hline & & $\begin{array}{l}\text { Butanol } \\
\text { extracts } \\
\end{array}$ & In vitro & $\begin{array}{l}\text { Cercariae of } S . \\
\text { manson }\end{array}$ & $\mathrm{LC}_{90}=18.5 \mathrm{mg} / \mathrm{L}$ & [44] \\
\hline & & $\begin{array}{l}\text { Methanol } \\
\text { extracts }\end{array}$ & In vivo & $\begin{array}{l}\text { Cercariae of } S . \\
\text { manson }\end{array}$ & The mortality (92\%) & {$[44]$} \\
\hline & & $\begin{array}{l}\text { Ethanol } \\
\text { extracts }\end{array}$ & In vivo & $\begin{array}{l}\begin{array}{l}\text { Cercariae of } S . \\
\text { manson }\end{array} \\
\text { mans }\end{array}$ & The mortality (40\%) & [44] \\
\hline & & $\begin{array}{l}\text { Butanol } \\
\text { extracts }\end{array}$ & In vivo & $\begin{array}{l}\text { Cercariae of } S . \\
\text { manson }\end{array}$ & The mortality (70\%) & {$[44]$} \\
\hline Cleomaceae & $\begin{array}{l}\text { Cleome } \\
\text { droserifolia }\end{array}$ & $\begin{array}{l}\text { Alcoholic } \\
\text { extract }\end{array}$ & In vivo & $\begin{array}{l}\text { Infected mice } \\
\text { with Schistosoma } \\
\text { mansoni }\end{array}$ & $\begin{array}{l}\text { CD extract resulted in a } \\
\text { weak reduction in worm }\end{array}$ & {$[27]$} \\
\hline Dryopteridaceae & $\begin{array}{l}\text { Dryopteris } \\
\text { filixmas } \\
\end{array}$ & $\begin{array}{l}\text { Methanolic } \\
\text { extracts }\end{array}$ & In vivo & $\begin{array}{l}\text { Schistosoma } \\
\text { mansoni } \text { worms }\end{array}$ & $\begin{array}{l}\text { Low anti-schistosomal } \\
\text { activity }\end{array}$ & [22] \\
\hline Fabaceae & Eriosema griseum & $\begin{array}{l}\text { Hydroalcohol } \\
\text { extract }\end{array}$ & In vitro & $\begin{array}{l}\text { Schistosomula, } \\
\text { Schistosoma } \\
\text { mansoni }\end{array}$ & Activity antischistosomal & {$[28]$} \\
\hline Lauraceae & $\begin{array}{l}\text { Cinnamomum } \\
\text { camphora }\end{array}$ & & In vivo & $\begin{array}{l}\text { Cercaria of } \\
\text { Schistosoma } \\
\text { japonicium }\end{array}$ & $\mathrm{CL}_{50}=0.07 \mathrm{mg} / \mathrm{L}$ & [29] \\
\hline \multirow[t]{2}{*}{ Lamiaceae } & $\begin{array}{l}\text { Ocimum } \\
\text { americanum }\end{array}$ & $\begin{array}{ll}\text { Hexane } & - \\
\text { OAH } & \\
\end{array}$ & In vitro & $\begin{array}{l}\text { Schistosoma } \\
\text { mansoni }\end{array}$ & $\begin{array}{ll}\begin{array}{l}\text { Low worm } \\
\text { percentage }\end{array} & \\
\end{array}$ & {$[30]$} \\
\hline & $\begin{array}{l}\text { Plectranthu } \\
\text { stenuiflorus }\end{array}$ & $\begin{array}{l}\text { Methanolic } \\
\text { extract }\end{array}$ & In vivo & $\begin{array}{l}\text { Schistosoma } \\
\text { mansoni }\end{array}$ & $\mathrm{IC}_{50}=17.39 \mathrm{mg} / 100 \mathrm{~mL}$ & [31] \\
\hline
\end{tabular}




\begin{tabular}{|c|c|c|c|c|c|c|}
\hline Family & Species & Extract & $\begin{array}{c}\text { In vivo/In } \\
\text { vitro }\end{array}$ & Larvae species & Effect & References \\
\hline & & & In vivo & Anti-cercaria & $\mathrm{IC}_{50}=12.29 \mathrm{mg} / 100 \mathrm{~mL}$ & {$[31]$} \\
\hline & & & In vivo & Anti-miracidium & $\mathrm{IC}_{50}=24.37 \mathrm{mg} / 100 \mathrm{~mL}$ & [31] \\
\hline Liliaceae & $\begin{array}{l}\text { Asparagus } \\
\text { stipularis Forssk }\end{array}$ & $\begin{array}{l}\text { Asparagalin } \\
\mathrm{A},\end{array}$ & In vitro & $\begin{array}{l}\text { Strain Schistosom } \\
\text { amansoni }\end{array}$ & Significant activity & [32] \\
\hline Lythraceae & $\begin{array}{l}\text { Punicagranatum } \\
\text { tannins }\end{array}$ & $\begin{array}{l}\text { Ethanol } \\
\text { extract }\end{array}$ & In vivo & $\begin{array}{l}\text { Miracidia of } \\
\text { Schistosom } \\
\text { amansoni }\end{array}$ & $\begin{array}{l}\text { Concentration as low as } \\
0.39 \mathrm{ppm}\end{array}$ & {$[33]$} \\
\hline \multirow[t]{2}{*}{ Myrtaceae } & $\begin{array}{l}\text { Syzygium } \\
\text { aromaticum }\end{array}$ & $\begin{array}{l}\text { Methanolic } \\
\text { extracts }\end{array}$ & In vivo & $\begin{array}{l}\text { Schistosoma } \\
\text { mansoni } \text { worms }\end{array}$ & $\begin{array}{l}\text { High anti-schistosomal } \\
\text { activity }\end{array}$ & {$[22]$} \\
\hline & $\begin{array}{l}\text { Callistemon } \\
\text { citrinus }\end{array}$ & $\begin{array}{l}\text { Aqueous } \\
\text { extract }\end{array}$ & In vivo & $\begin{array}{l}\text { Infected mice } \\
\text { with } S . \text { mansoni }\end{array}$ & $\begin{array}{l}\text { Significant decrease in } \\
\text { worm burden and tissue } \\
\text { egg load together }\end{array}$ & {$[45]$} \\
\hline Nitrariaceae & Peganum harmala & & In vitro & Cercaria & $\begin{array}{l}250 \mathrm{ppm} \text { up to } 1000 \mathrm{ppm} \\
\text { showed a } 100 \% \text { mortality } \\
\text { rate during the first half an } \\
\text { hour of exposure }\end{array}$ & {$[34]$} \\
\hline Phyllanthhaceae & Bridelia micranth & $\begin{array}{l}\text { Water extract- } \\
\text { BMW }\end{array}$ & In vitro & $\begin{array}{l}\text { Schistosoma } \\
\text { mansoni }\end{array}$ & $\begin{array}{ll}\begin{array}{l}\text { Low worm } \\
\text { percentage }\end{array} & \text { reduction } \\
\end{array}$ & {$[30]$} \\
\hline Pinaceae & Pinus canariensis & $\begin{array}{l}\text { Ethanol } \\
\text { extract }\end{array}$ & In vitro & $\begin{array}{l}\text { Worms } \\
\text { Schistosoma } \\
\text { mansoni }\end{array}$ & $\mathrm{LC}_{50}=12.8 \mathrm{ppm}$ & [21] \\
\hline \multirow[t]{3}{*}{ Punicaceae } & $\begin{array}{l}\text { Melaleuca } \\
\text { armillaris }\end{array}$ & Essential oil & In vivo & $\begin{array}{l}\text { Schistosoma } \\
\text { mansoni }\end{array}$ & $\begin{array}{l}\text { Both treatments } \\
\text { significantly ameliorated } \\
\text { the disturbing levels of } \\
\text { GSH and MDA in } \\
\text { infected mice }\end{array}$ & {$[35]$} \\
\hline & Punica granatum & $\begin{array}{l}\text { Peels and } \\
\text { leaves extracts }\end{array}$ & In vitro & $\begin{array}{l}\text { Schistosoma } \\
\text { mansoni worms }\end{array}$ & $100 \%$ death rate, 24 hours & {$[36]$} \\
\hline & Punica granatum & $\begin{array}{l}\text { peels and } \\
\text { leaves extracts }\end{array}$ & In vitro & $\begin{array}{l}\text { Schistosoma } \\
\text { mansoni }\end{array}$ & $100 \%$ death rate, 24 hours & {$[36]$} \\
\hline \multirow[t]{2}{*}{ Rubiaceae } & \multirow{2}{*}{$\begin{array}{l}\text { Mitracarpus } \\
\text { frigidus }\end{array}$} & \multirow{2}{*}{$\begin{array}{l}\text { Methanolic } \\
\text { extract }\end{array}$} & In vivo & Cercariae & Reduced total worm count & {$[37]$} \\
\hline & & & In vitro & Cercariae & Schistosomicidal activity & [37] \\
\hline \multirow[t]{2}{*}{ Rutaceae } & \multirow[t]{2}{*}{$\begin{array}{l}\text { Zanthoxylum. } \\
\text { leprieurii }\end{array}$} & $\begin{array}{l}\text { 1-Hydroxy-3- } \\
\text { methoxy-N- } \\
\text { methylacridon } \\
\text { e }\end{array}$ & In vitro & $\begin{array}{l}\text { Activity against } \\
\text { cercariae } \\
\text { Schistosoma } \\
\text { mansoni }\end{array}$ & $\mathrm{LC}_{50}=78.78 \mu \mathrm{g} / \mathrm{mL}$ & [38] \\
\hline & & Arborinine (3) & In vitro & $\begin{array}{l}\text { Activity against } \\
\text { cercariae } \\
\text { Schistosoma } \\
\text { mansoni }\end{array}$ & $\mathrm{LC}_{50}=6.98 \mu \mathrm{g} / \mathrm{mL}$ & {$[38]$} \\
\hline Sapindaceae & Dodonaea viscosa & $\begin{array}{l}\text { Aerial plant } \\
\text { part (leaves) } \\
\text { extracts }\end{array}$ & In vivo & $\begin{array}{l}\text { Mice infected } \\
\text { with } S . \text { mansoni }\end{array}$ & $\begin{array}{l}\text { Reduces the number of } \\
\text { eggs in hepatic tissues }\end{array}$ & [46] \\
\hline Simaroubaceae & $\begin{array}{l}\text { Eurycoma } \\
\text { longifolia }\end{array}$ & $\begin{array}{l}\text { Longilactone } \\
\text { (1) }\end{array}$ & In vitro & $\begin{array}{l}\text { Schistosoma } \\
\text { Japonicum }\end{array}$ & $\begin{array}{l}\text { Antischistosomal effect at } \\
\text { a concentration of } 200 \\
\mathrm{mg} / \mathrm{mL} \text {. }\end{array}$ & [39] \\
\hline Solanaceae & $\begin{array}{l}\text { Solanum } \\
\text { elaeagnifolium }\end{array}$ & $\begin{array}{l}\text { Ethanol } \\
\text { extract }\end{array}$ & In vitro & $\begin{array}{l}\text { Worms of } \\
\text { Schistosoma } \\
\text { mansoni }\end{array}$ & $\mathrm{LC}_{50}=6.0 \mathrm{ppm}$ & {$[21]$} \\
\hline Verbenaceae & $\begin{array}{l}\text { Clerodendrum } \\
\text { umbellatum }\end{array}$ & $\begin{array}{l}\text { Leaves } \\
\text { aqueous } \\
\text { extract }\end{array}$ & In vivo & $\begin{array}{l}\text { Schistosoma } \\
\text { mansoni (mice } \\
\text { model) }\end{array}$ & $\begin{array}{l}\text { In an important reduction } \\
\text { in faecal egg output by } \\
75.49 \% \text { and } 85.14 \% \text { for } \\
80 \mathrm{mg} / \mathrm{kg} \text { and } 160 \mathrm{mg} / \mathrm{kg}\end{array}$ & [10] \\
\hline
\end{tabular}

In parallel, the anti-miracidium activity of this extract was important $\left(\mathrm{IC}_{50}=24.37\right.$ $\mathrm{mg} / 100 \mathrm{~mL}$ ) [31]. Waiganjo and coworkers have shown that Ocimuma mericanum and Bridelia micrantha extracts had anti-schistosomal activity, as indicated by the high worm reduction [30].

In contrast, the methanol extract of Allium sativum proved to be the most potent, in vitro, for anti-schistosomal activity against adults of Schistosoma mansoni. However, these effects were less effective in vivo [22]. The aqueous extract of Clerodendrum umbellatum leaves demonstrated anti-schistosomal activity in vivo on a Schistosoma mansoni using mice 
as an animal model. The results showed that this extract resulted in an important reduction in fecal egg output by $75.49 \%$ and $85.14 \%$ at $80 \mathrm{mg} / \mathrm{kg}$ and $160 \mathrm{mg} / \mathrm{kg}$ of the extract, respectively [10]. This reduction was similar to that obtained in the group of mice treated with $100 \mathrm{mg} / \mathrm{kg}$ of praziquantel [10]. In another study, the stem bark and roots of Rauwolfia vomitoria were found to be active against cercariae and adult worms. Indeed, within 2 hours of exposure, all the cercariae were killed at concentrations ranging from 62.5 to $1000 \mu \mathrm{g} / \mathrm{mL}$ and from 250 to $1000 \mu \mathrm{g} / \mathrm{mL}$, respectively [23]. Furthermore, all adult worms exposed to concentrations varied from 250 to $1000 \mu \mathrm{g} / \mathrm{mL}$. For both plant parts, they died within 120 hours of incubation [23]. The effect of the crude extract of Cleome droserifolia leaves on mice experimentally infected with Schistosoma mansoni showed that this extract slightly reduced the worm burden $(32.46 \%)$ and affected the viability of both mature and immature eggs [27]. On the other hand, the extract of peels and leaves of Punica granatum significantly affected adult $S$. mansoni worms and schistosomes, with a death rate of $100 \%$, after 24 hours of exposure to plant extract [36].

\subsection{Anti-schistosomal activity of plant essential oils.}

Essential oils are volatile compounds known by their various biological effects, including anti-schistosomal activity [25, 35]. Interestingly, the essential oil of Ageratum conyzoides caused an interesting dose-dependent reduction in the number of eggs of S. mansoni [25]. In another study, the essential oil of the fresh leaves of Melaleuca armillaris rich in 1,8cineole, terpinene-4-ol, and limonene was evaluated by Rizk et al. (2012) for its antischistosomal activity in vivo. Consequently, they found that this essential oil significantly ameliorated the disturbing levels of proteins, including natural antioxidant enzymes such as malondialdehyde and glutathione in infected mice [35].

\subsection{Anti-schistosomal activity of plant bioactive compounds.}

Several investigations have evaluated the anti-schistosomal activity of compounds derived from medicinal plants. Indeed, two compounds derived from A. nubigena (luteolin and (3R,6R)-linalool oxide acetate) showed anti-schistosomal activity against $S$. mansoni with IC50 range from 5.8 to $36.9 \mu \mathrm{g} / \mathrm{mL}$ [24].

Furthermore, the linalool-rich extracts from Cinnamomum camphora exhibited striking larvicidal and molluscicidal effects with $\mathrm{LC}_{50}=0.25 \mathrm{mg} / \mathrm{L}$ against Oncomelania hupensis and $\mathrm{LC}_{50}=0.07 \mathrm{mg} / \mathrm{L}$ against cercaria of $S$. japonicium [29]. Likewise, this bioactive compound significantly reduced the schistosomulum recovered from mouse skin after infection by challenge [29].

In contrast, Zondegoumba et al. (2019) evaluated the in vitro schistosomicidal property of two compounds (1-Hydroxy-3-methoxy-N-methylacridone and Arborinine) isolated from the fruits of Zanthoxylum leprieurii. The results showed that these two compounds exhibited remarkable cytotoxicity against cercariae with $\mathrm{LC}_{50}$ values of 78.78 and $6.98 \mu \mathrm{g} / \mathrm{mL}$, respectively [38]. In another work, the administration of asparagaline A (isolated from the roots of Asparagus stipularis) has been shown to retard the worm growth [32]. Additionally, Longilactone isolated from Eurycoma longifolia leaves exhibited a significant antischistosomal effect at a concentration of $200 \mathrm{mg} / \mathrm{mL}$ [39].

\section{Conclusions}


Several medicinal plants have shown important anti-schistosomal activities. These effects are related to the presence of bioactive compounds such as flavonoids, alkaloids, phenolic acids, and terpenoids. In addition, the anti-schistosomal investigation of these molecules showed that they possess important activities with several targets. This review shows that medicinal plants are an important source for discovering anti-schistosomal drugs. However, further investigations concerning these bioactive compounds' toxicity and clinical trials are required to validate their therapeutic potential.

\section{Funding}

This research received no external funding.

\section{Acknowledgments}

This research has no acknowledgment.

\section{Conflicts of Interest}

The authors declare no conflict of interest.

\section{References}

1. McManus, D.P.; Dunne, D.W.; Sacko, M.; Utzinger, J.; Vennervald, B.J.; Zhou X.N. Schistosomiasis. Nature Reviews: Disease Primers 2018, 4, https://doi.org/10.1038/s41572-018-0013-8.

2. Cetron, M.S.; Chitsulo, L.; Sullivan, J.J.; Pilcher, J.; Wilson, M.; Noh, J.; Tsang, V.C.; Hightower, AW.; Addiss, D.G. Schistosomiasis in Lake Malawi. Lancet 1996, 348, 1274-1278, https://doi.org/10.1016/S01406736(96)01511-5.

3. Utzinger, J.; Raso, G.; Brooker, S.; De Savigny, D.; Tanner, M.; Ørnbjerg, N.; N'goran, E.K. Schistosomiasis and neglected tropical diseases: towards integrated and sustainable control and a word of caution. Parasitology 2009, 136, 1859-1874, https://doi.org/10.1017/s0031182009991600.

4. Cioli, D.; Pica-Mattoccia, L.; Archer, S. Antischistosomal drugs: past, present and future? Pharmacology \& therapeutics 1995, 68, 35-85, https://doi.org/10.1016/0163-7258(95)00026-7.

5. $\quad$ Gryseels, B.; Mbaye, A.; De Vlas, S.J.; Stelma, F.F.; Guisse, F.; Van Lieshout, L.; Faye, D.; Diop, M.; Ly, A.; Tchuem-Tchuenté, L.A.; Engels, D. Are poor responses to praziquantel for the treatment of Schistosoma mansoni infections in Senegal due to resistance? An overview of the evidence. Tropical medicine \& international health 2001, 6, 864-873, https://doi.org/10.1046/j.1365-3156.2001.00811.x.

6. Wang, W.; Wang; L.; Liang, Y.S. Susceptibility or resistance of praziquantel in human Schistosomiasis: a review. Parasitology research 2012, 111, 1871-1877, https://doi.org/10.1007/s00436-012-3151-z.

7. McCullough, F.S.; Gayral, P.H.; Duncan, J.; Christie, J.D. Molluscicides in schistosomiasis control. Bulletin of the World Health Organization 1980, 58.

8. Ndamba, J.; Nyazema, N.; Makaza, N.; Anderson, C.; Kaondera, K.C. Traditional herbal remedies used for the treatment of urinary Schistosomiasis in Zimbabwe. Journal of Ethnopharmacology 1994, 42, 125-132, https://doi.org/10.1016/0378-8741(94)90106-6.

9. Neto, A.G.; da Silva Filho, A.A.; Costa, J.M.L.C.; Vinholis, A.H.C.; Souza, G.H.B.; Cunha, W.R.; Silva, M.L.A.E.; Albuquerque, S.D.; Bastos, J.K. Evaluation of the trypanocidal and leishmanicidal in vitro activity of the crude hydro-alcoholic extract of Pfaffia glomerata (Amarathanceae) roots. Phytomedicine 2004, 11, 662-665, https://doi.org/10.1016/j.phymed.2003.06.005

10. Jatsa, H.B.; Sock, T.M.; Tchuente, L.A.; Kamtchouing, P. Evaluation of the in vivo activity of different concentrations of Clerodendrumum bellatum Poir against Schistosoma mansoni infection in mice. African Journal of Traditional, Complementary and Alternative Medicines 2009, 6.

11. El Ridi, R.; Aboueldahab, M.; Tallima, H.; Salah, M.; Mahana, N.; Fawzi, S.; Mohamed, S.H.; Fahmy, O.M. In vitro and in vivo activities of arachidonic acid against Schistosoma mansoni and Schistosoma haematobium. Antimicrobial agents and chemotherapy 2010, 54, 3383-3389, https://doi.org/10.1128/aac.00173-10.

12. Sundaraneedi, M.K.; Tedla, B.A.; Eichenberger, R.M.; Becker, L.; Pickering, D.; Smout, M.J. Polypyridylruthenium (II) complexes exert anti-schistosome activity and inhibit parasite acetylcholinesterases. PLoS neglected tropical diseases 2017, 11, https://doi.org/10.1371/journal.pntd.0006134. 
13. Walker, A.J. Insights into the functional biology of schistosomes. Parasit and Vectors 2011, 4, 1-15, https://doi.org/10.1186/1756-3305-4-203.

14. Dreyfuss, G.; Rondelaud, D. Les mollusques dans la transmission, des helminthiases humaines et vétérinaires. Bulletin Académique et Vétérinaire de France 2011, 164.

15. Gentilini, M.; Games, E.; Danis, M.; Mouchet, J.; Duflo, B.; Lagardére, B.; Richard le noble, D.; Boucker, G. Medicine tropicale. Livre, $5 e ́$ édition, Medecine Sciences, Paris, F lammarion 1993, 928, 221-35.

16. Balahbib, A.; Amarir, F.; Corstjens, P.L.; Claudia, J.; van Dam, G.J.; Hajli, A.; Belhaddad, M.; El Mansouri, B.; Sadak, A.; Rhajaoui, M.; Adlaoui, E.B. Selecting accurate post-elimination monitoring tools to prevent reemergence of urogenital Schistosomiasis in Morocco: a pilot study. Infectious diseases of poverty 2017, 6 , https://doi.org/10.1186/s40249-017-0289-z.

17. Mouahid, G.; Rognon, A.; de Carvalho Augusto, R.; Driguez, P.; Geyer, K.; Karinshak, S. Transplantation of schistosome sporocysts between host snails: A video guide. Wellcome Open Research 2018, 3.

18. Charles, H.; king, M.D. Toward elimination of Schistosomiasis. The New England Journal of Medicine 2009 , 360, 106-109.

19. Fenwick, A.; Rollinson, D.; Southgate, V. Implementation of humans chistosomiasis control: challenges and prospects. Adv.Parasitol 2006, 61, 567-622, https://doi.org/10.1016/S0065-308X(05)61013-5.

20. Doenhoff, M.J.; Cioli, D.; Utzinger, J. Praziquantel: mechanisms of action, resistance and new derivatives for Schistosomiasis. Current opinion in infectious diseases 2008, 21, 659-67, https://doi.org/10.1097/qco.0b013e328318978f.

21. Yousif, F.; Hifnawy, M.S.; Soliman, G.; Boulos, L.; Labib, T.; Mahmoud.; Ramzy, S.F.; Yousif, M.; Hassan, I.; Mahmoud, K.; El-Hallouty, S.M. Large-scale in vitro screening of Egyptian native and cultivated plants for schistosomicidal activity. Pharm Biol 2007, 45, 501-510, https://doi.org/10.1080/13880200701389425.

22. Metwalley, K.M. Assessment of the anti-schistosomal activity of some plant extracts against Schistosoma mansoni infection. World J Med Sci 2015, 12, 162-169.

23. Tekwu, E.M.; Bosompem, K.M.; Anyan, W.K.; Appiah-Opong, R.; Owusu, K.B.A.; Tettey, M.D.; Kissi, F.A.; Appiah,A.A.; Beng, V.P.; Nyarko, A.K. In vitro assessment of anthelmintic activities of Rauwolfia vomitoria (Apocynaceae) stem bark and roots against parasitic stages of schistosoma mansoni and cytotoxic study. Journal of parasitology research 2017, 2017, https://doi.org/10.1155/2017/2583969.

24. Wangchuk, P.; Pearson, M.S.; Giacomin, P.R.; Becker, L.; Sotillo, J.; Pickering, D.; Smout, M.J.; Loukas A. Compounds derived from the Bhutanese daisy, Ajanianubigena, demonstrate dual anthelmintic activity against Schistosoma mansoni and Trichuris muris. PLoSneglected tropical diseases 2016, 10, https://doi.org/10.1371/journal.pntd.0004908.

25. De Melo, N.I.; Magalhaes, L.G.; De Carvalho, E.; Wakabayashi, K.A.; Aguiar, D.P.; Ramos, R.C.; Mantovani, A.L.; Turatti, I.C.; Rodrigues, V.; Groppo, M.; Cunha, W.R. Schistosomicidal activity of the essential oil of Ageratum conyzoidesL.(Asteraceae) against adult Schistosoma mansoni worms. Molecules 2011, 16, 762-773, https://doi.org/10.3390/molecules16010762.

26. de Oliveira, R.N.; Rehder, V.L.G.; Oliveira, A.S.S.; Jeraldo, V.D.L.S.; Linhares, A.X.; Allegretti, S.M. Anthelmintic activity in vitro and in vivo of Baccharistrimera (Less) DC against immature and adult worms of Schistosoma mansoni. Experimentalparasitology $\quad \mathbf{2 0 1 4}, \quad 139, \quad 63-72$, https://doi.org/10.1016/j.exppara.2014.02.010.

27. El-Shenawy, N.S.; Soliman, M.F.; Abdel-Nabi, I.M. Does Cleome droserifolia have anti-schistosomiasis mansoniactivity?Revista do Instituto de Medicina Tropical de São Paulo 2006, 48, 223-228, https://doi.org/10.1590/S0036-46652006000400010.

28. Kone, W.M.; Vargas, M.; Keiser, J. Anthelmintic activity of medicinal plants used in Côte d'Ivoire for treating parasitic diseases. Parasitology research 2011, 110, 2351-2362, https://doi.org/10.1007/s00436011-2771-z.

29. Yang, F.; Long, E.; Wen, J.; Cao, L.; Zhu, C.; Hu, H.; Yang, X. Linalool, derived from Cinnamomum camphora (L.) Presl leaf extracts, possesses molluscicidal activity against Oncomelania hupensis and inhibits infection of Schistosoma japonicum. Parasites\& vectors 2014, 7, https://doi.org/10.1186/17563305-7-407.

30. Waiganjo, N.; Yole, D.; Ochanda, H. Anti-Schistosomal activity of five plant extracts on Swiss white mice infected with Schistosoma mansoni. Journal of Pharmacy and Biological Sciences 2016, 9, 49-53, https://doi.org/10.9790/3008-09164953.

31. Aziz, I.A.; El-bady, A.; El-Gayed, S.H. In vitro anti-schistosomal activity of "Plectranthus tenuiflorus" on miracidium, cercaria and schistosomula stages of Schistosoma mansoni. Research Journal of Parasitology2011, 6, 74-82.

32. El-Seedi, H.R.; El-Shabasy, R.; Sakr, H.; Zayed, M.; El-Said, A.; Helmy, K.M.; Boulos, L. Antischistosomiasis triterpene glycoside from the Egyptian medicinal plant Asparagus stipularis. Revista Brasileira de Farmacognosia2012, 22, 314-318, https://doi.org/10.1590/S0102-695X2012005000004.

33. Abozeid, K.; Shohayeb, M.; Ismael, A. In vitro tests for efficacy of tannins extracted from pomegranate (Punicagranatum) against Schistosoma mansoni miracidia. Journal of Science and Technology2012, 13, 5565. 
34. Osman, E.A.; Koko, W.; Mohammed, Z.; Galal, M. Anticercarial Activity of The Plant Peganum harmala (Harmal) Crude Extracts. University of Africa Journal of Sciences 2012, 2, 126-138.

35. Rizk, M.; Ibrahim, N.; El-Rigal, N. Comparative in vivo antioxidant levels in Schistosoma mansoni infected mice treated with praziquantel or the essential oil of Melaleuca armillaris leaves. Pakistan journal of biological sciences: Pakistan Journal of Biological Sciences2012,15, 971-978, http://dx.doi.org/10.3923/pjbs.2012.971.978.

36. Fahmy, Z.H.; El-Shennawy, A.M, El-Komy, W.; Ali, E.; Hamid, S.A. Potential antiparasitic activity of pomegranate extracts against shistosomules and mature worms of Schistosoma Mansoni: in vitro and in vivo study. Australian Journal of Basic and Applied Sciences2009, 3, 4634-4643.

37. Fabri, R.L.; Aragão, D.M.D.O.; Florêncio, J.R.; Pinto, N.D.C.C.; Mattos, A.C.A.; Coelho, P.M.Z.; Scio, E. Chromatographic fingerprint analysis and effects of the medicinal plant species Mitracarpus frigidus on adult Schistosoma mansoni worms. BioMed research international2014, 2014, https://doi.org/10.1155/2014/941318.

38. Zondegoumba, E.N.T.; Dibahteu, W.L.; de Araujo. A.; Vidari, G.; Liu, Y.; Luo, S.; Tullius, M. Cytotoxic and Schistosomidal Activities of Extract, Fractions and Isolated Compounds from Zanthoxylum leprieurii (Rutaceae). International Journal of Sciences: Basic and Applied Research 2019, 44, 209-222.

39. Jiwajinda, S.; Santisopasri, V.; Murakami, A.; Kawanaka, M.; Kawanaka, H.; Gasquet, M.; Ohigashi, H. In vitro anti-tumor promoting and anti-parasitic activities of the quassinoids from Eurycoma longifolia, a medicinal plant in Southeast Asia. Journal of Ethnopharmacology2002, 82, 55-58, https://doi.org/10.1016/S0378-8741(02)00160-5.

40. Rodrigues, J. G. M.; Albuquerque, P. S. V.; Nascimento, J. R.; Campos, J. A. V.; Godinho, A. S.; Araújo, S. J.; Negrão-Corrêa, D. A. The immunomodulatory activity of Chenopodium ambrosioides reduces the parasite burden and hepatic granulomatous inflammation in Schistosoma mansoni-infection. Journal of Ethnopharmacology 2020, 264, 113287. https://doi.org/10.1016/j.jep.2020.113287.

41. Chacha, M. Schistosomacidal Activity of Lannea Schimperi and Searsia Longipes against Cercariae, Schistosomula and Adult Stage of Schistosoma Mansoni. Chronicles of Pharmaceutical Science 2019, 3, 787-799.

42. Feussom, N. G.; Jatsa, H. B.; Kenfack, M. C.; Nkondo, E. T.; Femoe, U. M.; Fassi, J. B. K.; Tchuente, L. A. T. In vitro Activity of Ozoroa pulcherrima Schweinf. Extracts and Fractions on Schistosoma mansoni Cercariae and Adult Worms. European Journal of Medicinal Plants 2020, 17-30. https://doi.org/10.9734/ejmp/2020/v31i830256

43. Jatsa, H. B.; Feussom, N. G.; Nkondo, E. T.; Kenfack, M. C.; Simo, N. D.; Fassi, J. B. K.; Kamtchouing, P. Efficacy of Ozoroa pulcherrima Schweinf methanolic extract against Schistosoma mansoni-induced liver injury in mice. Journal of Traditional and Complementary Medicine 2019,9, 304-311. https://doi.org/10.1016/j.jtcme.2017.08.009.

44. Aly, I.; Gouida, M. S.; Sayed, H. E.; Attiyah, S. M.;Shaker, S.; Elleboudy, N. A.; Ghoname, S. I. Efficiency of Three Extracts of Carica papaya as Molluscicidal and Anti-schistosomal Agents against Biomphalaria alexandrina and Schistosoma mansoni by Flow Cytometry. Journal of Pharmaceutical Research International 2020, 31-41. https://doi.org/10.9734/jpri/2020/v32i1130543.

45. El-Refai, S. A.; Atia, A. F. ; Mahmoud, S. F. Effects of Callistemon citrinus aqueous extract on prepatent and patent infections with Schistosoma mansoni in experimentally infected mice. Journal of helminthology 2019, 93, 424-433. https://doi.org/10.1017/S0022149X1800041X.

46. Bawazir, S. S.; Badawi, I. H.; Hassan, E. A. Effects of Dodonaea viscosa Ethanolic Extract on Experimental Schistosomiasis in Mice. Egyptian Academic Journal of Biological Sciences, E. Medical Entomology \& Parasitology 2020, 12, 11-19. https://doi.org/10.21608/eajbse.2020.68124. 